\title{
Honokiol Inhibits Nitric Oxide-Induced Apoptosis in Rabbit Articular Chondrocytes via PI-3K/AKT Pathway
}

\author{
Won Kil Lee and Song Ja Kim* \\ Department of Biological Sciences, College of Natural Sciences, Kongju National University, Gongju 314-701, Korea \\ Received July 29, 2010 / Accepted October 9, 2010
}

\begin{abstract}
Honokiol is a small molecular weight ligand originally isolated from the Chinese medicinal herb Magnolia officinalis, a plant used in traditional Chinese and Japanese medicine [9]. In a previous study, the effects of honokiol were shown to have anti-angiogenic, anti-invasive and anti-proliferative activities in a variety of cancers $[1,3,4,11,13,17,24,29,30]$. We showed previously that direct production of nitric oxide (NO) by treatment of NO donor, sodium nitroprusside (SNP), led to apoptosis in rabbit articular chondrocytes $[15,16]$. This study confirmed that NO-induced apoptosis was suppressed by honokiol treatment in a dose-dependent manner as determined by cell phenotype, MTT assay, Western blot analysis and FACS analysis in articular chondrocytes. Treatment of honokiol inhibited SNP-induced expression of p53 as well as DNA fragmentation in articular chondrocytes, but increased expressionof pro-caspase-3. Inhibition of SNP-induced apoptosis by honokiol treatment was rescued by LY294002, the specific inhibitors of phosphoinositide 3-kinase (PI-3K) in articular chondrocytes. Our results indicate that honokiol inhibits NO-induced apoptosis via PI-3K/AKT pathway in rabbit articular chondrocytes.
\end{abstract}

Key words : Honokiol, apoptosis, PI-3K/AKT pathway

\section{Introduction}

Honokiol $\left[\mathrm{C}_{18} \mathrm{H}_{18} \mathrm{O}_{2}\right.$, molecular weight=266.33] (Fig. 1) is $\mathrm{TNFa}$-related a small molecular weight ligand,originally isolated from the Chinese medicinal herb 'Magnolia officinalis', a plant used in traditional Chinese and Japanese medicine of many diseases [9]. Honokiol, one of the major phenolic constituents of magnolia bark, have several pharmacological effects such as anti-oxidant [20], anti-thrombosis [26], anti-bacterial, xanthine oxidase inhibition, anti-tumor, anti-platelet aggregation, anti-inflammatory effects [19], anti-arrhythmic [18] and anxiolytic effect [28]. Previous reports have demonstrated that honokiol exhibited remarkable inhibitory effects on mouse skin tumor promotion in an in vivo two-stage carcinogenesis, and inhibited the growth of human leukemic HL-60 cells [8]. Moreover, honokiol has induced apoptosis which characterized by DNA fragmentation and apoptotic bodies in human lymphoid leukemia Molt 4B cell [11].

Chondrocytes in cartilage are differentiated from mesenchymal cells during embryonic development. Differentiated chondrocytes, which are the only cell type found in normal

\section{*Corresponding author}

Tel : +82-41-850-8507, Fax : +82-41-850-0927

E-mail : ksj85@kongju.ac.kr mature cartilage, synthesize sufficient amounts of cartilage-specific extracellular matrix (ECM) to maintain matrix integrity. This homeostasis is demolished in degenerative diseases, such as osteoarthritis (OA) and rheumatoid arthritis (RA) $[7,23]$. Arthritis is characterized by structural and biochemical changes in chondrocytes and cartilage, including degradation of cartilage matrix, insufficient synthesis of ECM caused loss of chondrocyte phenotype.

It is now generally accepted that proinflammatory cytokines, such as interleukin-1 beta (IL-1 $\beta$ ) and tumor necrosis factor-alpha (TNFa), play a predominant role in structural and biochemical alterations in chondrocyte and cartilage [7]. One of the leading mechanisms by which cytokines elicit their effects on cartilage involves the stimulation of nitric oxide (NO) production via inducible NO synthase [2,21]. Although NO-induced cartilage destruction is caused by

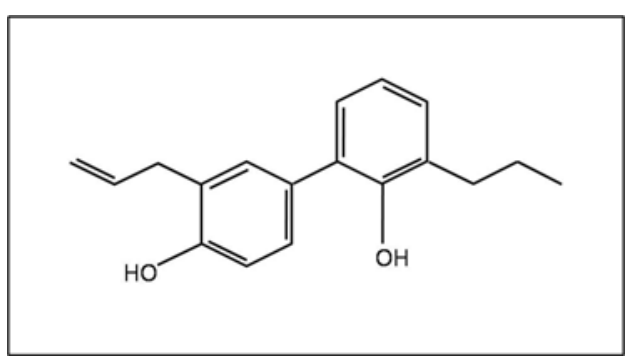

Fig. 1. Molecular structure of honokiol. $\left(\mathrm{C}_{18} \mathrm{H}_{18} \mathrm{O}_{2}, \mathrm{MW}=266.33\right)$ 
various factors, increased apoptotic cell death $[5,10,31]$ and loss of differentiated phenotype of articular chondrocytes $[6,25]$ appear to be important contributors. Our previously results showed that direct production of NO by treatment of NO donor, sodium nitroprusside (SNP), in primary cultured articular chondrocytes, led to apoptosis, dedifferentiation, and cyclooxygenase (COX)-2 expression via a complex protein kinase signaling cascade involving mitogen-activated protein (MAP) kinase and protein kinase $\mathrm{C}$ (PKC) [14-16].

However, the regulatory mechanism of NO-induced apoptosis has not been clearly elucidated yet. This study addressed the effects of honokiol on the regulation of NO-induced apoptosis by SNP, and suggests that inhibition of No-induced apoptosis by honokiol is required for PI-3 Kinase-dependent pathway.

\section{Materials and Methods}

\section{Cell culture}

Rabbit articular chondrocytes were isolated from cartilage slices of 2-week-old New Zealand white rabbits by enzymatic digestion as described previously [33]. Cartilage slices were dissociated enzymatically for $6 \mathrm{hr}$ in $0.2 \%$ collagenase type II (381 U/mg solid, Sigma, Louis, MO) in Dulbecco's modified Eagle's medium (DMEM) (Gibco-BRL, Gaithersburg, MD). Individual cells were suspended in DMEM supplemented with $10 \%$ (v/v) fetal bovine-calf serum, $50 \mathrm{~g} / \mathrm{ml}$ streptomycin, and 50 units $/ \mathrm{ml}$ penicillin, after which and they were then plated on culture dishes at a density of $5 \times 10^{4}$ cells $/ \mathrm{cm}^{2}$. The medium was changed every 2 days after seeding, and cells reached confluence in approximately 5 days. The 3.5 day cell cultures were treated with honokiol. Honokiol was purchased from Wako (Wako, Osaka) and a stock solution (MW: 266.33, $100 \mathrm{mM}$ ) in DMSO prepared and stored at $4^{\circ} \mathrm{C}$ The following pharmacological agents were added $1 \mathrm{hr}$ prior to honokiol, LY294002 to inhibit PI-3 kinase. LY294002 war obtained from BioMol (BioMol, PA).

\section{Western blot analysis}

Whole cell lysates were prepared by extracting proteins using a buffer containing $50 \mathrm{mM}$ Tris-HCl, $\mathrm{pH}$ 7.4, $150 \mathrm{mM}$ $\mathrm{NaCl}, 1 \%$ Nonidet P-40, and $0.1 \%$ sodium dodecylsulfate (SDS), supplemented with protease inhibitors $[10 \mathrm{~g} / \mathrm{ml}$ leupeptin, $10 \mathrm{~g} / \mathrm{ml}$ pepstatin $\mathrm{A}, 10 \mathrm{~g} / \mathrm{ml}$ aprotinin and $1 \mathrm{mM}$ of 4-(2-aminoethyl) benzenesulfonyl fluoride] and phosphatase inhibitors $\left(1 \mathrm{mM} \mathrm{NaF}\right.$ and $\left.1 \mathrm{mM} \mathrm{Na} \mathrm{VO}_{4}\right)$. The lysa- teswere size-fractionated by SDS-polyacrylamide gel electrophoresis and transferred to a nitrocellulose membrane. The nitrocellulose sheet was then blocked with 3\% non-fat dry milk in Tris-buffered saline. Expression of caspase-3 and pAkt were detected using antibody purchased from Cell Signaling Technology (Danvers, MA), and p53 and Actinwere detected using antibodies purchased from Santa Cruz Biotechnology (Santa Cruz, CA). Blots were developed using a peroxidase-conjugated secondary antibody and visualized with an ECL system.

\section{Cell Proliferation assay}

We used the MTT assay to quantify the proliferation of cells treated with honokiol and with SNP. Cells were seeded in 96-well plates at a density of $2 \times 10^{4}$ cells per well for 24 $\mathrm{hr}$. Cells were treated with honokiol and were treated with SNP. $10 \mu$ MTT reagent 1 was added to the cells per well. The plate was incubated for $4 \mathrm{hr}$ at $37^{\circ} \mathrm{Cuntil}$ purple formazan crystal developed. And, $100 \mu \mathrm{l}$ MTT reagent 2 was added to the cells per well. After overnight in incubator, the absorbance at $600 \mathrm{~nm}$ was read and four wells were examined with a spectrophotometer for each treatment.

\section{Cell cycle distribution by FACS analysis}

Cell cycle distribution was assessed by staining DNA content with propidium iodide as previously described method [12] with some modifications. Briefly, chondrocytes were plated at a density of $2 \times 10^{5}$ cells per 35 -mm culture dish and incubated for $24 \mathrm{hr}$. Fresh complete media containing serially diluted honokiol were replaced to culture dishes and further incubated for $24 \mathrm{hr}$. After incubation, both adherent and floating cells were harvested and fixed with $80 \%$ ethanol in PBS overnight. Fixed cells were incubated with RNase A $(50 \mu \mathrm{g} / \mathrm{ml})$ for $25 \mathrm{~min}$ prior to staining nucleic acid with propidium iodide $(50 \mathrm{\mu g} / \mathrm{ml})$ for $5 \mathrm{~min}$. The DNA content of $2 \times 10^{4}$ cells in each group was analyzed by flow cytometer (Partec $\mathrm{GmbH}$, Münster, Germany) and the results were demonstrated as histograms of DNA content. Quantification of the distinct cell cycle phases was calculated using the FloMax program.

\section{DNA fragmentation}

Cellular DNA was extracted after treatment of indicated honokiol with SNP for $24 \mathrm{hr}$. Briefly, whole cells were washed with PBS and resuspended with lysis buffer containing $50 \mathrm{mM}$ Tris- $\mathrm{HCl}$ (pH 7.5), $20 \mathrm{mM}$ EDTA, and 1\% NP-40. After centrifugation at 3,000 rpm for $5 \mathrm{~min}, 10 \mu \mathrm{l}$ of $10 \%$ 
SDS and $10 \mu \mathrm{l}$ of $50 \mathrm{mg} / \mathrm{ml}$ RNase A were added to the supernatants, and then incubated at $56^{\circ} \mathrm{C}$ for $2 \mathrm{hr}$. 2Subsequently, $10 \mu \mathrm{l}$ of proteinase $\mathrm{K}(2.5 \mathrm{mg} / \mathrm{ml})$ was added and further incubated at $37^{\circ} \mathrm{C}$ for $2 \mathrm{hr}$. DNA was allowed to precipitate with 0.5 volume of $10 \mathrm{M}$ ammonium acetate and 2.5 volume of cold ethanol of total volume at $-70^{\circ} \mathrm{C}$ for overnight. Extracted DNA was dissolved in $25 \mu \mathrm{l}$ of 10 $\mathrm{mM}$ Tris- $\mathrm{HCl}$ buffer ( $\mathrm{pH}$ 8.0) containing $1 \mathrm{mM}$ EDTA. Two micrograms of DNA samples were resolved electrophoretically on a $2 \%$ agarose gel and visualized under UV transilluminator.

\section{Data analyses and statistics}

The results are expressed as the means \pm S.E. values calculated from the specified number of determinations. A Student's t-test was used to compare individual treatments with their respective control values. A probability of $\mathrm{p}<0.05$ was taken as denoting a significant difference.

\section{Result}

\section{Honokiol suppress NO-induced apoptosis in rabbit articular chondrocytes}

NO mediates the regulation and survival of chondrocyte phenotype by inducing apoptosis. To assess anti-apoptosis effect of honokiol in NO-induced apoptotic cells, various does $(1 \mu \mathrm{M}-10 \mu \mathrm{M})$ of honokiol and $1 \mathrm{mM}$ SNP were treated in cells. The cell morphology observed by phase-contrast microscope showed that NO-induced apoptosis was inhibited by honokiol treatment (Fig. 2A). Honokiol significantly blocked NO-induced apoptotic death of chondrocytes in a dose-dependent manner, consistent with the pattern of cell morphology (Fig. 2B). As anticipated, p53 expression also decreased in a dose-dependent manner as determined by
A.

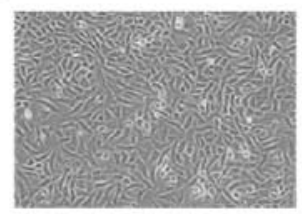

Control

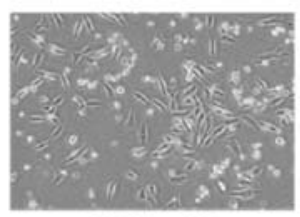

SNP 1 mM

c.

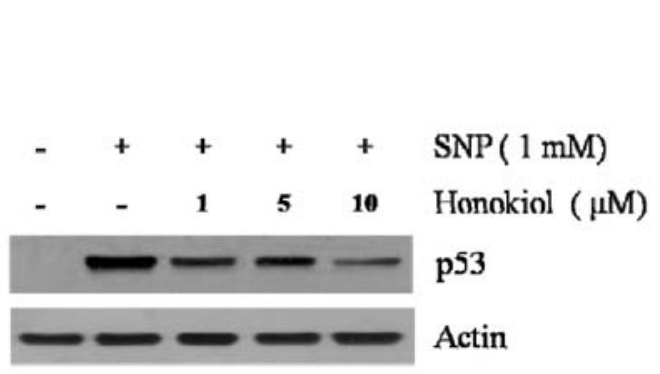

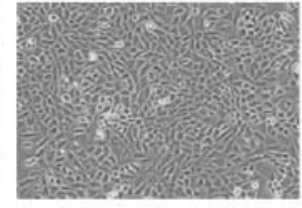

Honokiol $10 \mu \mathrm{M}$

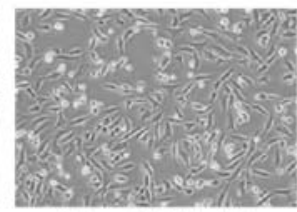

Honokiol $10 \mu \mathrm{M}$ SNP 1 mM
B.

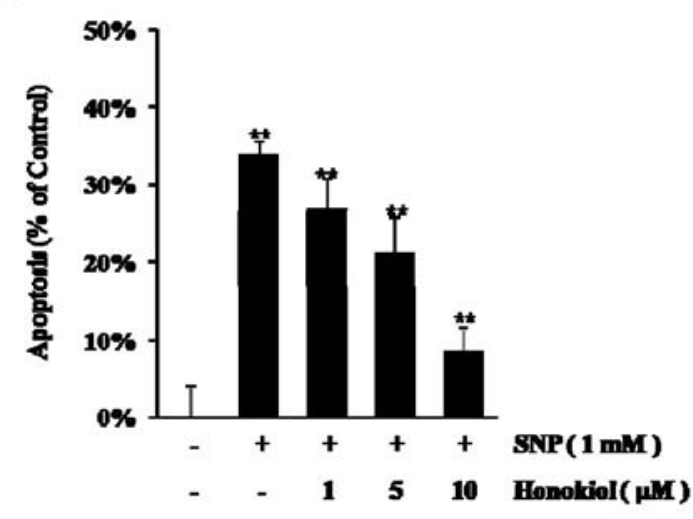

D.

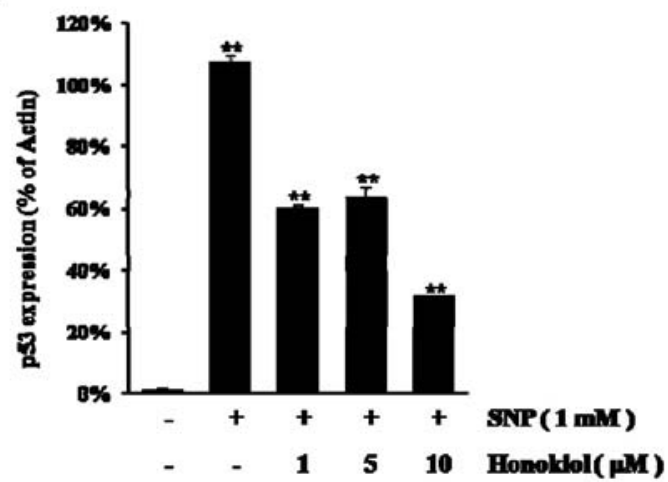

Fig. 2. NO-induced apoptosis were inhibited Honokiol dose-dependent manner in rabbit articular chondrocytes. Articular chondrocytes were untreated (control) or treated with $1 \mathrm{mM} \mathrm{SNP}$ and $10 \mu \mathrm{M}$ of honokiol plus $1 \mathrm{mM}$ SNP for $24 \mathrm{hr}$. The apoptotic cells death was determined by phase-contrast microscope (magnification, 200X) (A). Primary chondrocytes apoptosis were determined by MTT assay (B) and expression of p53 and actin was determined by western blot analysis. Actin was used as loading control (C). It was determined that the protein levels of p53 were subsequently quantified by densitometric analysis (D). Statistically significant differences between control and other treatment: ${ }^{*} p<0.005,{ }^{* *} p<0.0001$. 
A.
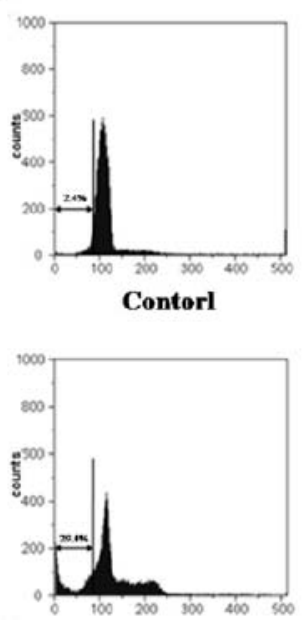

SNP 1 mM

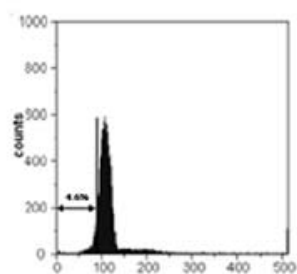

Honokiol10 $\boldsymbol{\mu M}$

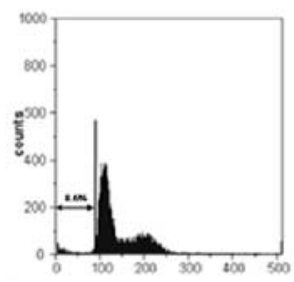

Honokiol $10 \mu \mathrm{M}$ SNP 1 mM
B.

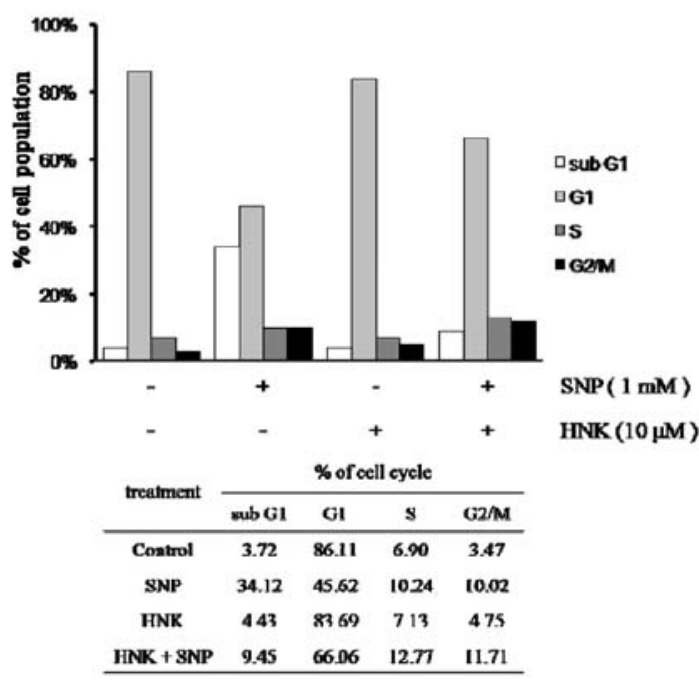

Fig. 3. Honokiol inhibited NO-induced apoptosis in rabbit articular chondrocytes. Chondrocytes were untreated (control) or treated with $1 \mathrm{mM}$ SNP and $10 \mu \mathrm{M}$ of honokiol plus $1 \mathrm{mM} \mathrm{SNP}$ for $24 \mathrm{hr}$. The apoptotic cells death was determined by FACS analsis (A). Each phase of cell cycle was calculated using FloMax program (B). The cells were fixed with $80 \%$ ethanol in PBS, stained with propridium iodide (PI).

A.

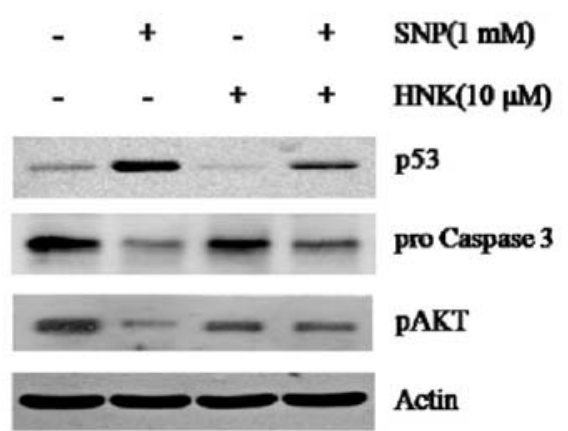

c.

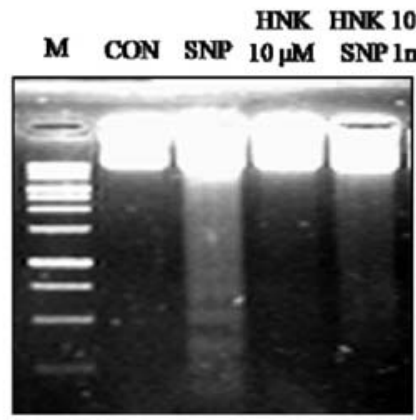

B.

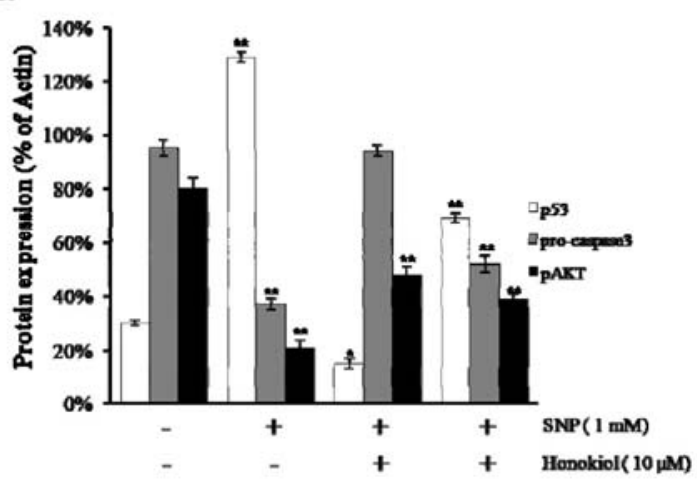

Fig. 4. Honokiol suppressed expression of p53 and caspase-3. Also it protected NO-induced DNA damagein rabbit articular chondrocytes. Articular chondrocytes were untreated (control) or treated with $1 \mathrm{mM} \mathrm{SNP}$ and $10 \mu \mathrm{M}$ of honokiol plus 1 mM SNP for $24 \mathrm{hr}$. Expression of p53 and Caspase-3 inhibited honokiol treatment by western blot analysis. Actin was used as loading control (A). Actin was a protein loading control. It was determined that the protein levels of p53, pro-casepase-3 and pAKT were subsequently quantified by densitometric analysis (B). The DNA damage protection of honokiol was determined by DNA fragmentation (C). 
Western blot analysis quantified by densitometric analysis respectively (Fig. 2C and 2D).

Apoptotic cell death was blocked in chondrocytes with SNP $(1 \mathrm{mM})$ and honokiol $(10 \mu \mathrm{M})$ for $24 \mathrm{hr}$ (Fig. 3A). This result was demonstrated as histograms of DNA content. The distribution of cells in each phase of cell cycle was calculated using FloMax program (Fig. 3B, upper and lower panel). As shown in Fig. 3B, about 34\% of the cells were increased at sub G1 phase and $46 \%$ of the cells decreased at G1 phase after treatment with SNP alone compared with those in controls. When SNP was combined with honokiol, the cells of sub G1 phase were dramatically decreased and the cells of G1 phase were increased compared with those in SNP treatment cells. The results indicate that induction of apoptosis was occured by transition of G1 cells to sub G1 cells.

To elucidate the mechanism of honokiol-regulated apoptosis, caspase-3, an executioner of cell death, and p53, a signaling molecule upstream of caspase- 3 , were examined, and phosphorylation of AKT, known as a survival signaling molecule downstream of PI-3K was also investigated in rabbit articular chondrocytes (Fig. 4A). SNP-induced p53 was blocked by treatment of honokiol, effectively. As anticipated, pro-caspase-3 and pAKT expression was rescued by treatment of honokiol. It was determined that the protein levels of p53, pro-casepase- 3 and pAKT were subsequently quantified by densitometric analysis (Fig. 4B). Consistent with the result of Fig. 4A, honokiol significantly blocked NO-induced apoptotic cell death, as determined by DNA fragmentation (Fig. 4C). These results indicate that honokiol effectively recovered NO caused apoptotic cell death in rabbit articular chondrocytes.

Inhibitory effect of honokiol on the NO-induced apoptosis is required for PI-3K/AKT-dependent pathway

To further investigate anti-apoptotic effects regulated by honokiol, LY294002, a well known signaling molecule up-

A.

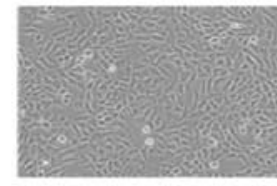

Control

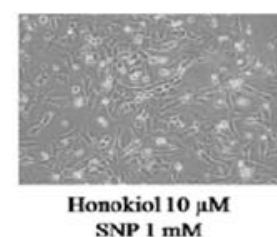

C.

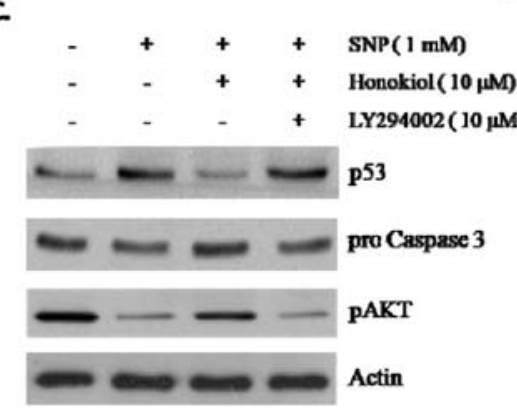

B.
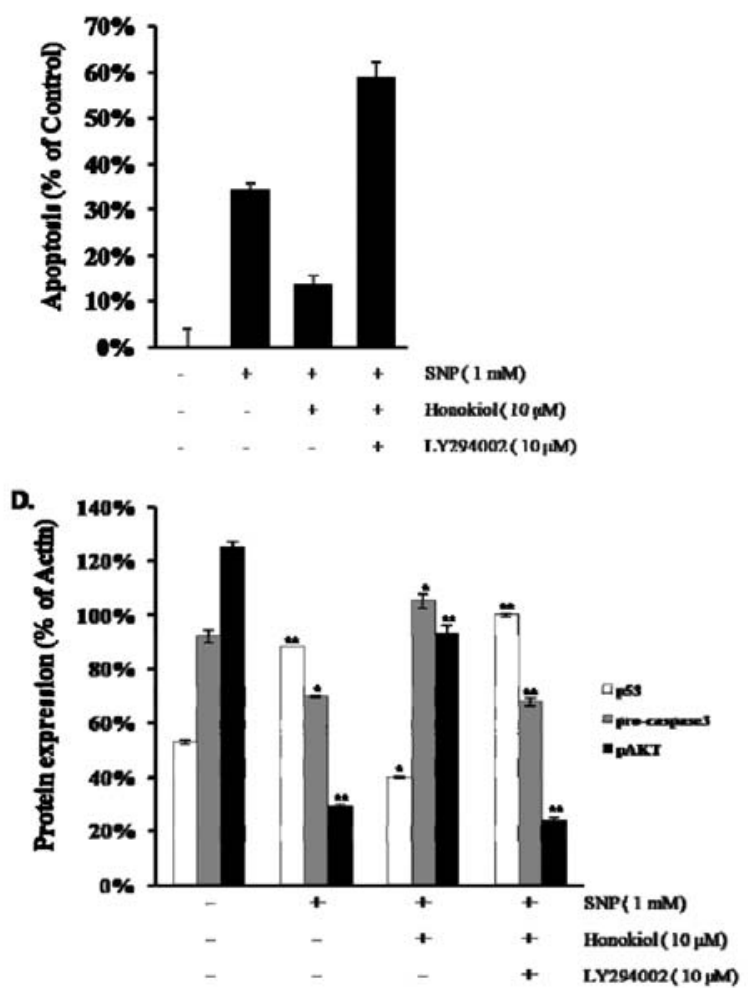

Fig. 5. Inhibitory effect of NO-induced apoptosis by honokiol treatment is required for PI-3K/AKT-dependent pathway. Primary cultured chondrocytes were untreated (control), treated with $1 \mathrm{mM} \mathrm{SNP}$ and $10 \mu \mathrm{M}$ honokiol and $10 \mu \mathrm{M}$ LY294002 for 24 $\mathrm{hr}$. The apoptic cells death was determined by phase-contrast microscope (magnification, 200X) (A). Apoptosis of chondrocytes were determined by MTT assay (B) and expression of p53, caspase-3, pAKT and actin was determined by western blot analysis. Actin was used as loading control (C). It was determined that the protein levels of p53, pro-casepase-3 and pAKT were subsequently quantified by densitometric analysis (D). Statistically significant differences between control and other treatment: ${ }^{*} p<0.005,{ }^{* *} p<0.0001$. 
stream of PI-3K/AKT was treated in chondrocytes to block activation of PI-3K/AKT. In consequence, anti-apoptotic effects of honokiol were significantly inhibited in chondrocytes (Fig. 5A), and these inhibition by LY294002 increased NO-induced apoptosis (Fig. 5B). LY294002 increases suppression of the p53 which honokiol leads. However increase of pro-caspase-3 is inhibited by LY294002 in articular chondrocytes (Fig. 5C). These protein levels were quantified by densitometric analysis (Fig. 5D). These findings collectively suggest that PI3K/AKT is required for inhibition of NO-induced apoptosis by honokiol in articular chondrocytes.

\section{Discussion}

Recently, alternative mechanisms of action have been proposed to account for the anti-tumor effect of honokiol and many studies have been initiated to explore the anti-tumor efficacy of honokiol. Also, the growth inhibition of tumor by honokiol is highly related to cell cycle arrest at the G0/G1 phase and induction of apoptosis [27].

NO mediates the regulation and survivalof chondrocyte phenotype by inducing dedifferentiation and apoptosis. Our previous results showed that apoptosis of chondrocyte caused by direct production of $\mathrm{NO}$ with the $\mathrm{SNP}$ is regulated by opposite functions of two mitogen-activated protein kinase subtypes, extracellular signal-regulated kinase-1/-2 (ERK-1/-2) and p38 kinase, in association with the elevation of p53 protein level, caspase- 3 activation, and differentiation status [14-16]. SNP treatment stimulated activation of both ERK-1/-2 and p38 kinase. The activated ERK-1/-2 plays a role as an inhibitory signal for NO-induced apoptosis, whereas p38 kinase functions as a signal for the maintenance of the differentiated status and an inducing signal for apoptosis of chondrocytes. And, we also reported that NO production in articular chondrocytes inhibits cell survival signaling, including apoptosis [22]. IGF-1 inhibits NO-induced apoptosis and dedifferentiation by modulating actin cytoskeletal architecture. Actin cytoskeleton regulates these functions by modulating PI-3K, AKT, MAPK, and PKC-a and $-\zeta$ signaling. Thus, inhibition of NO-induced apoptosis by disruption of the actin cytoskeleton is consistent with the suppression of the apoptotic signaling pathway, such as activation of p38 kinase, inhibition of PKC- $a$ and $-\zeta$, NFactivation, p53 accumulation, and caspase-3 activation. These data additionally indicate that disruption of the actin cytoskeleton blocks NO-induced inhibition of the PI-3K/
AKT. Moreover, inhibition of the PI-3K/AKT pathways is required for the blockage of $\mathrm{p} 38$ kinase activation, inhibition of PKC- $a$ and $-\zeta$, NF- $k B$ activation, accumulation of p53, and caspase-3 activation.

Based on this finding, we investigated whether honokiol treatment modulates the cell survival signal to block NO-induced apoptosis. Here we demonstrate that NO-induced apoptosis was suppressed by Honokiol treatment as determined by phase contrast microscophy, FACS analysis and DNA fragmentation. And, these anti-apoptotic effects were significantly recovered by LY294002, a PI-3K/AKT specific inhibitor. Thus, blocking of pAKT activation by treatment with LY294002 effectively rescued honokiol-inhibited p53 protein expression level. However increase of pro-caspase-3 is inhibited by LY294002 in articular chondrocytes. These results indicate that honokiol is helpful to prevent destruction of cartilage caused by OA or RA.

\section{Acknowledgement}

This work was supported by a National Research Foundation of Korea (NRF) grant funded by the Korean Government (MEST) (2010-0003239 \& 2009-0084569).

\section{References}

1. Ahn, K. S., G. Sethi, S. Shishodia, B. Sung, J. L. Arbiser, and B. B. Aggarwal. 2006. Honokiol potentiates apoptosis, suppresses osteoclastogenesis, and inhibits invasion through modulation of nuclear factor-kappaB activation pathway. Mol. Cancer Res. 4,621-633.

2. Amin, A. R and S. B. Abramson. 1998. The role of nitric oxide in articular cartilage breakdown in osteoarthritis. Curr. Opin. Rheumatol. 10, 263-268.

3. Bai,X., F. Cerimele, and M. Ushio-Fukai. 2003. Honokiol, a small molecular weight natural product, inhibits angiogenesis in vitro and tumor growth in vivo. J. Biol. Chem. 278, 35501-35507.

4. Battle, T. E., J. Arbiser, and D. A. Frank. 2005. The natural product honokiol induces caspase-dependent apoptosis in B-cell chronic lymphocytic leukemia (B-CLL) cells. Blood 106, 690-697.

5. Blancco,F, J., R. Guitian, E. Vazquez-Martul, F. J. de Toro, and F. Galdo. 1998. Osteoarthritis chondrocytes die by apoptosis. A possible pathway for osteoarthritis pathology. Arthritis Rheum. 41, 284-289.

6. Cao, M., A. westerhausen-Larson, C. Niyibizi, K. Kavalkovich, H. I. Georgescu, C. F. Rizzo, P. A. Hebda, M. Stefanovic-Racic, and C. H. Evans. 1997. Nitric oxide inhibits the synthesis of type-II collagen without altering Col2A1 
mRNA abundance: prolyl hydroxylase as a possible target. Biochem. J. 324, 305-310.

7. Choy, E. H., and G. S. Panayi. 2002. Cytokine pathways and joint inflammation in rheumatoid arthritis. N. Engl. J. Med. 344, 907-916.

8. Fong, W. F., A. K. Tse, K. H. Poon, and C. Wang. 2005. Magnolol and honokiol enhance HL-60 human leukemia cell differentiation induced by 1,25-dihydroxyvitamin D3 and retinoic acid. Int. J. Biochem. Cell Bio.l 37, 427-441.

9. Fujita, M., H. Itokawa, and Y. Sashida. 1973. Studies on the componets of Magnolia obovata Thunb $\Pi \pm$ on the components of the methanol extrct of the bark. Yakugaku Zasshi 93, $422-428$.

10. Hashimoto, S., R. L. Oches, S. Komiya, and M. Lotz. 1998. Linkage of chondrocyte apoptosis and cartilage degradation in human osteoarthritis. Arthritis Rheum. 41, 1632-1638.

11. Hibasami, H., Y. Achiwa, and H. Katsuzakil. 1998. Honokiol induces apoptosis in human lymphoid leukemia Molt 4B cells. Int. J. Mol. Med. 2, 671-673.

12. Im, J. H. and S. J. Kim. 2010. Paclitaxel induced caspase-independent mitotic catastrophe in rabbit articular chondrocyte. J. Life Sci. 20, 519-527

13. Ishitsuka, K., T. Hideshima, and M. Hamasaki. 2005. Honokiol overcomes conventional drug resistance in human multiple myeloma by induction of caspase-dependent and -independent apoptosis. Blood 106, 1794-1800.

14. Kim, S. J., H. G. Kim, C. D. Oh, Y. M. Yoon, W. K. Song, J. H. Kim, Y. J. Yoo, O. S. Bang, S. S. Kang, and J. S. Chun. 2002. p38 kinase-dependent and -independent Inhibition of protein kinase $\mathrm{C}$ zeta and -alpha regulates nitric oxide-induced apoptosis and dedifferentiation of articular chondrocytes. J. Biol. Chem. 277, 30375-30381.

15. Kim, S. J., J. W. Ju, C. D. Oh, Y. M. Yoon, W. K. Song, J. H. Kim, Y. J. Yoo, O. S. Bang, S. S. Kang, and J. S. Chun. 2002. ERK-1/2 and p38 kinase oppositely regulate nitric oxide-induced apoptosis of chondrocytes in association with p53, caspase-3, and differentiation status. J. Biol. Chem. 277, 1332-1339.

16. Kim, S. J., S. G. Hwang, D. Y. Shin, S. S. Kang, and J. S. Chun. 2002. p38 kinase regulates nitric oxide-induced apoptosis ofarticular chondrocytes by accumulating p53 via NFkappa B-dependent transcription and stabilization by serine 15 phosphorylation. J. Biol. Chem. 277, 33501-33508.

17. Konoshima, T., M. Kozuka, and H. Tokuda. 1991. Studies on inhibitors of skin tumor promotion, IX. Neolignans from Magnolia officinalis. J. Natural Products 54, 816-822.

18. Liou, K. T., S. M. Lin, S. S. Huang, C. L. Chih, and S. K. Tsai. 2003. Honokiol ameliorates cerebral infarction from ischemia-reperfusion injury in rats. Planta Med. 69, 130-134.

19. Liou, K. T., Y. C. Shen, C. F. Chen, C. M. Tsao, and S. K. Tsai. 2003. The anti-inflammatory effect of honokiol on neutrophils: mechanisms in the inhibition of reactive oxygen species production. Eur. J. Pharmacol. 475, 19-27.
20. Lo, Y. C., C. M. Teng, C. F. Chen, C. C. Chen, and C. Y. Hong. 1994. Magnolol and honokiol isolated from Magnolia officinalis protect rat heart mitochondria against lipid peroxidation. Biochem. Pharmacol. 9, 549-553.

21. Martel-Pelletier, J., N. Alaaeddine, and J. P. Pelletier. 1999. Cytokines and their role in the pathophysiology of osteoarthritis. Front. Biosci. 4, 694-703.

22. Oh,C. D., S. H. Chang, Y. M. Yoon, S. J. Lee, Y. S. Lee, S. S. Kang, and J. S. Chun. 2000. Opposing role of mitogen-activated protein kinase subtypes, Erk-1/2 and p38, in the regulation of chondrogenesis of mesenchymes. J. Biol. Chem. 275, 5613-5619.

23. Sandell, L. J. and T. Aigner. 2001. Articular cartilage and changes in arthritis. An introduction: cell biology of osteoarthritis. Arthritis Res. 3, 107-113.

24. Shigemura, K., J. L. Arbiser, and S. Y. Sun. 2007. Honokiol, a natural plant product, inhibits the bone metastatic growth of human prostate cancer cells. Cancer 109, 1279-1289.

25. Taskiran, D., M. Stefanovic-Racic, H. Georgescu, and C. Evans. 1994. Nitric oxide mediates suppression of cartilage proteoglycan synthesis by interleukin-1. Biochem. Biophys. Res. Commun. 200, 142-148.

26. Teng, C. M., C. C. Chen, F. N. Ko, L. G. Lee, T. F. Huang, Y. P. Chen, and H. Y. Hsu. 1988. Two antiplatelet agents from Magnolia officinalis. Thromb Res. 50, 757-765.

27. Wang, T. , F. Chen, Z. Chen, Y. F. Wu, X. L. Xu, S. Zheng, and X. Hu. 2004. Honokiol induces apoptosis through p53-independent pathway in human colorectal cell line RKO. World J. Gastroenterol. 10, 2205-2208.

28. Watanabe, K., H. Watanabe, Y. Goto, M. Yamaguchi, N. Yamamoto, and K. Hagino. 1983. Pharmacological properties of magnolol and honokiol extracted from Magnolia officinalis: central depressant effects. Planta Med. 49, 103-108.

29. Wolf, I., J. O'Kelly, and N. Wakimoto. 2007. Honokiol, a natural biphenyl, inhibits in vitro and in vivo growth of breast cancer through induction of apoptosis and cell cycle arrest. Int. J. Oncol. 30, 1529-1537.

30. Yang, S. E., M. T. Hsieh, T. H. Tsai, and S. L. Hsu. 2002. Down-modulation of Bcl-XL, release of cytochrome $\mathrm{c}$ and sequential activation of caspases during honokiol-induced apoptosis in human squamous lung cancer $\mathrm{CH} 27$ cells. Biochem. Pharmacol. 63, 1641-1651.

31. Yatsugi, N., T. Tsukazaki, M. Osaki, T. Koji, S. Yamashita, and H. Shindo. 2000. Apoptosis of articular chondrocytes in rheumatoid arthritis and osteoarthritis: correlation of apoptosis with degree of cartilage destruction and expression of apoptosis-related proteins of p53 and c-myc. J. Orthop. Sci. 5, 150-156.

32. Yoon, Y. M., S. J. Kim, C. D. Oh, J. W. Ju, W. K. Song, Y. J. Yoo, T. L. Huh, and J. S. Chun. 2002. Maintenance of differentiated phenotype of articular chondrocytes by protein kinase $\mathrm{C}$ and extracellular signal-regulated protein kinase. J. Biol. Chem. 277, 8412-8420. 


\title{
초록 : Honokiol에 의한 토끼의 무릎 연골세포에서 PI-3K/AKT pathway를 통하여 nitric oxide에 의해 유도되는 세포사멸의 억제
}

\author{
이원길 - 김송자* \\ (공주대학교 자연과학대학 생명과학과)
}

Honokiolo은 작은 분자량을 갖는 중국의 약초인 'Magnolia officinalis'에서 추출한 리간드로서 중국과 일본에서 전통 의약제로 사용되어 왔다. 이전 연구에서는 honokiol이 다양한 종류의 암에서anti-angiogenic, anti-invasive, anti-proliferative activities 등의 다양한 효과가 있는 것으로 알려져 있다. 우리는 이전 연구에서 Nitric oxide donor인 sodium nitroprusside (SNP)에 의해서 토끼 무릎관절연골세포에서 세포사멸이 일어나는 것을 보고하였 다. 본 연구에서는 무릎 연골세포에서 NO에 의해 유도되는 세포사멸이 honokiol 처리농도에 의존적으로 억제되 는 것을 세포형태, MTT assay, Western blot analysis 그리고 FACS를 통해 확인할 수 있었다. 또한, honokiol은 $\mathrm{SNP}$ 에 의해 유도되는 p53의 발현 및 pro-caspase-3의 활성 저해, DNA fragmentation을 억제하였다. Honokiol에 의한 세포사멸 억제는 PI-3K의 특정 저해제인 LY294002를 SNP와 honokiol과 함께 처리하였을 때 세포의 사멸이 증가하는 것을 확인할 수 있었다. 이는 honokiol이 PI-3K/AKT pathway를 통하여 NO가 유도하는 세포사멸을 억제하는 것을 의미한다. 